\title{
Stage I Ampulla of Vater Cancer AJCC v8
}

National Cancer Institute

\section{Source}

National Cancer Institute. Stage I Ampulla of Vater Cancer A/CC v8. NCI Thesaurus. Code C134866.

Stage I includes: IA: (T1a, N0, M0); IB: (T 1b, N0, M0); (T2, N0, M0). T1a: T umor limited to ampulla of Vater or sphincter of Oddi. T1 b: Tumor invading beyond the sphincter of Oddi (perisphincteric invasion) and/or into the duodenal submucosa. T2: Tumor invading into the muscularis propria of the duodenum. N0: No regional lymph node metastasis. M0: No distant metastasis. (AJCC 8th ed.) 